\title{
"THE SLEEPERS" \\ AND SOME WHITMAN NOTES
}

\author{
R. S. MISHRA
}

The THIRD NOTEBOoK of Whitman's Daybooks and Notebooks, in the section, "Other Notebooks, \&c.on Words," consists of 24 unnumbered pages. ${ }^{1}$ Both the notebook and "The Sleepers" 2 essentially describe Whitman's autobiographical endeavor in understanding the nature of friendship and the poetic self.

The "flocks of ideas" that come "chirping" to Whitman in this notebook are not without connections: He observes that the mystery, power and joy of friendship ("the efflux of the soul") seem "capricious" because it is not the ordinary kind of friendship based on necessary distinctions - on sexual distinction, for example. The discovery of it is a poetic act and the source of the poet's power. This is a perception of beauty and a truly religious feeling. The unusual nature and birth of friendship ("adhesiveness") makes the poet believe that even "Death and Poverty and Wickedness" are "caches" of beauty.

Whitman, the "I" and "the poet" are implicitly connected in the notes. This is one of the reasons for the "ideas" coming to him "chirping" and "twittering," alive with feelings. The basic problem that haunts Whitman in the notes is how to establish a link between his homosexuality and his power and identity as a poet:

Why be there men I meet, and others I know, that while they are with me, the sunlight of Paradise / theme-expands my blood - that if when I walk with an arm of theirs around my neck, my soul teoper like like scoots and courses like

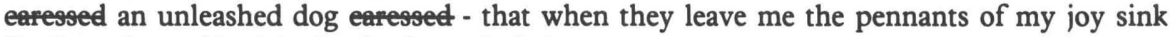
flat the and lank in the deadest calm? ${ }^{3}$

Thus the search for "the poet" is his autobiographical struggle with his own fate as a man and poet. It is not merely a search for a dramatic image. However, to call him homosexual in the dictionary sense is a distortion of his profound need and effort to find such a link. Therefore, with the obvious homosexual implications of friendship in the notes it is necessary to recognize that Whitman is also suggesting a kind of sexual emotion ("the subtle chloro-/form of our spirits") that defies discriminations of age, sex and looks. ("Though But she is neither young nor fair complexioned? . . . men rough, not handsome, not accomplished-.") ${ }^{4}$ His "love" is "boundless" because it breaks through conventional boundaries. 
This brings us to the poem where the same autobiographical struggle can be seen in a more comprehensive and clearer manner than in the notes. "The Sleepers" is a hymn to the night because it is the spirit of the night that overwhelms the "I" with "friendliness," and the essential nature of this friendship lies in seeing through the necessary distinctions of the day: "Elements merge in the night, ships make tacks in dreams." This image of a change of course is finely contrasted with the shipwreck in Section 4.

Shipwrecks are not unreal: "I search with the crowd, not one of the company is wash'd to us alive / In the morning I help pick up the dead and lay them in a barn." And like the shipwreck there are other scenes of death and loss - the death of the "beautiful, gigantic swimmer," sad memories of "the older war-days" and sad separations. But the reality of these scenes is no more or less than an aspect of reality. In fact, in the total context of the poem these isolated scenes of "Death and Poverty and Wickedness" (in the language of the notebook) are perceptions of reality in the distinguishing terms of the day. During the day the ordinary day-to-day world cannot function without making the necessary distinctions of the day and night, life and death, sickness and health, man and woman, right and wrong. However, these distinctions split the universe of joy and friendship. By way of contrast, it is interesting to note how these individually described events of death and loss in single and separate sections are "averaged" in one swift paragraph in Section 7 (11. 132-163). In the night nothing is seen in isolation, individually, in a distinguishing manner. With the averaging grace of the night the sharp contours of individual episodes are smoothed out.

If the ships change their course, they return home "well-fill'd." They are not wrecked by the sea. This fulfillment is possible in a dream in the night. Here the word dream does not mean unreal. What is suggested is that a new way of looking at life may restore the split universe. In this way the ships enter into a new reality - the reality of friendship and joy-a world where every wound is healed, identities are "merged," the "slave" and the "master" become one, all "flow hand in hand." This merging and flowing clearly indicate the dissolutions of distinctions.

Thus the "I" contrasts in the poem two views of reality, and the poem is not about the chemistry of the night but how the "I" becomes one with the sleepers, how he accepts the night-view of the world against the day-view. In other words, Whitman defines his homosexual impulses of going beyond sexual and other distinctions as a creative power to break through the discriminating intelligence which casts its own net (day-view) on the nature of things.

Characteristically the poem opens with the "I" who is in a transitional stage. He is within the world of the night but is yet to become the spirit of the night. The transition from the day to the night is not an easy one because they produce different aspects of the same scene. That is why, in this 
Their President and their Pet! I see them lead him now. - I see his large, slow gait - his face illuminated like the face of an arm-bound child. Onward he moves with the gay procession, and the laughing pioneers, and the wild trilling bugles of joy. 5

What is important here is not just a repetition of words and phrases in the poem but the way these are repeated. In the notes the above passage has many trial lines in pages [7] and [8]. This means that Whitman is not engaged casually with the "idea" expressed here. As I have indicated before, the "I" and the "Poet" are not different. The poet and the "ten million supplewristed gods" are not ritualizing a sexual awakening into adulthood (a concept of the day-world - the capacity to distinguish and judge), but they are discovering together "beauty" in the world. The poet is both the "President" and the "Pet" of these gods because the relationship is of undiscriminating friendship and joy. Briefly, the hide-and-seek underlines the fact that true awarenes of life is possible through play, dance or abandon. And from other references in the notes it can be seen that it is a religious awakening-the world is seen as a mirthful dance. If this spirit of abandon shows a faith in the essential order of the universe and points to the possibilities of man's freedom, it is in a sense socially subversive. This is why, Whitman insists in the notes, the efflux of the soul "comes through beautiful gates of laws" and concedes that at the present stage of social evolution it could seem "capricious."

The argument in the poem runs a similar course. When the burden and duty of observing a whole and beautiful world, of grading and dividing it is over, it is all dance and laughter. This is an initiation not into sexual adulthood but into a condition where such social and psychological norms are meaningless. Appropriately, the "I" does not become a dancer but a dance: "I am a dance." In the whirl of joy the consciousness of one's identity is lost. When a dancer knows that he is a dancer, he operates within the systems of the day. He is not one with the dance. His discriminating mind interferes in the totality of joy. Hence in this wild mirth the I is both the "boss" and the "pet." The whole passage is alive with pictures of speed and movementa wild spirit, as it were, breaks all walls, all laws that confine man's sense of essential and complete unity with the universe:

I am the actor, the actress, the voter, the politician,

The emigrant and the exile, the criminal that stood in the box,

He who has been famous and he who shall be famous after to-day,

The stammerer, the well-form'd person, the wasted or feeble person. [11. 42-45]

With the knowledge of this unity Whitman conveys his subtle sense of sexuality. His deliberate confusion of the identities of the lovers (11. 46-59) means that the I can no longer see his love as a lover-and-beloved affair but as a love for all things. This is not to say that Whitman is de-humanizing 
transitional stage he is "confused" and "ill-assorted." To begin the poem at this point means that there is a day-world to which all the sleepers belong in the day which is a world of innumerable contradictions, and that there is a possibility for going beyond this day-world which the " $\mathrm{I}$ " is precisely trying to do. So he sees the sleepers in lines 1 to 25 individually, discriminately. But he also knows that they are "sleeping": "The night pervades them and infolds them." The "I" sees from two levels at the same time. "How solemn they look there, stretch'd and still" accurately describes the relation of the "I" to the sleepers at this transitional stage. They are seen as individual objects ("the white features of corpses" and also the happy "married couple"), but there is a tendency to see them as one single experience. Once the meaning of this experience dawns upon him through love ("I pass my hands soothingly . . ."), or once the "I" becomes one with the spirit of the night, the "new beings" leap into view.

From line 26 to 59 it is this becoming that is celebrated. The "pausing, gazing, bending, and stopping" I becomes "a dance" and the "shut," "quite," "stretch'd," "solemn" and "still" sleepers become "nimble ghosts." Surely this transformation is the central issue in the poem. And the connections with the notebook are nowhere clearer. The comparative lines are quoted below:

I am a dance-play up there! the fit is whirling me fast!

I am the ever-laughing-it is new moon and twilight,

I see the hiding of douceurs, I see nimble ghosts whichever way I look,

Cache and cache again deep in the ground and sea, and where it is neither ground nor sea.

Well do they do their jobs those journeyman divine,

Only from me can they hide nothing, and would not if they could,

I reckon I am their boss and they make me a pet besides,

And surround me and lead me and run ahead when I walk,

To lift their cunning covers to signify me with stretch'd arms, and resume the way;

Onward we move, a gay gang of blackguards! with mirth-shouting music and wild-flapping pennants of joy! [11. 32-41]

And this is from the notebook:

I think ten million supple-fingered wristed gods are perpetually always employed hiding beauty in the world - burying it every where in every thing - and most of all in spots that men and women do not think of and never look - as Death and Poverty and Wickedness. - Cache! and Cache again! all over the earth, and in the heavens that swathe the earth, and in the waters of the sea. - They do their jobs well; those journeymen divine. Only from the Poet they can hide nothing and would not if they could. - I reckon he is Boss of those gods; and the work they do is done for him; and all they have concealed, they have concealed for his sake. Him they attend indoors and outdoors. - They run ahead when he walks, and lift their cunning covers and signify him with pointed stretched arms. 
his love. The sweat of the lover is a clear reminder of that. His search for gentle love is an extension of his humanity. The "fading away" is a dying into greater richness. At this point the first movement of the I comes to an end.

And the second movement begins:

I descend my western course, my sinews are flaccid,

Perfume and youth course through me and I am their wake. [11. 60-61]

It is clear that the verb "descend" implies a verbal action contrasted with the activity of the I in Section 1, which ends, "I fade away." The lowering of experiential altitude ("descend") coupled with a sense of tiredness ("flaccid") indicates that the following series of episodes (in Sections 2, 3, 4, 5, 6) embody experiences at a different level of awareness. But the swift transition to youth and movement in the next line shows that these experiences are now lived through the consciousness of the I who is already gifted with the grace of the night. (So the phrase "my western course," which is for Whitman a progressive movement, and the word "wake" with its implied image of a moving ship are important.) In other words, these essentially dayexperiences are now seen through the eyes of the I who has seen the beauty of the night.

Earlier I commented on these episodes as individual events of death and loss. This is one aspect of their meaning. But the contintuity of these events in a sequential organization which constitutes the second movement of the I, from Sections 2 to 6 , reveals another. It is the capacity of the I to see them with the transforming glance of the night. In a sense, these episodes are presented in two ways simultaneously.

Thus the three brief scenes of old age, bereavement, and death are not described as "evil or pain." So, while the old woman's face is "yellow and wrinkled," she is darning her "grandson's stocking." And the I is identified with the old woman in both these situations: the woman's old age and her hope and love for the grandson. Similarly, while the widow is "sleepless" (pining for her husband), she can "see sparkles of starshine on the icy and pallid earth." And even the dead body, while it is "blank," is not "wretched." The sense of suffering is neither accentuated nor dismissed. This even temper actually influences and modulates all other scenes of death and loss that follow Section 2.

The poet's sense of sympathy with what is dead, lost and gone has a strange inner balance, which neither exaggerates nor understates the evil and pain in life. So the meticulous description of the death of the swimmer does not release a flood of tears, but a strange perspicuity which controls the sense of death and destruction. This kind of control is also behind, "In the morning I help pick up the dead and lay them in rows in a barn." Similarly, 
Washington, who suffers separations in war (the slaughter of his soldiers) and in peace (with love), finally "shakes hands and bids good-bye to the army." And the red squaw who "never came nor was heard of" again remained in the mother's memory as an image of "beauty and purity."

It is this extremely difficult virtue of encountering death and suffering and at the same time possessing an inner poise that makes the merging and dissolving of distinctions in the poem a moral force, not flabbiness. Hence the I reaffirms the glory of the night in his third and last movement in the last two hymn-like Sections (7 and 8).

In the notebook, under reference, Whitman wondered, "(What is the eause meaning, any how, of my tove attachment adhesiveness for toward others?- What is the cause of theirs tove for toward me?) - (Am I loved by them boundlessly because my love for them is more boundless?-)" 6 In the poem no such questions hang over him because he has found a link between his so-called homosexual friendship and his creative personality:

A show of summer softness - a contact of something unseen
$\quad$-an amour of the light and air,
I am jealous and overwhelm'd with friendliness ...
I swear they are all beautiful,
Every one that sleeps is beautiful, every thing in the dim light
is beautiful,
The wildest and bloodiest is over, and all is peace. [11. 117-118, 144-146)

Whitman's literary effort is a definition of this creative personality. Therefore, "The Sleepers" is essentially an autobiographical quest.

Finally, the night is not seen as the opposite of the day ("the rich running day") but as an alternative possibility. "I will duly pass the day $\mathrm{O}$ my mother, and duly return to you"-this is a perfect concluding line to the whole poem. The repetition of "duly" is Whitman's way of emphasizing on the integrity of every moment, every knowledge. In fact, without this the grace of the night becomes merely a dream, and not a dream of truth. In the poem the "I" experiences a liberation from his I-ness, which is a condition of the day. In the night the "I" cannot choose but be "you." The I-you, we-they distinctions fade away into a new life.

University of East Anglia, Norwich, U.K.

\section{NOTES}

1 Walt Whitman, Daybooks and Notebooks, edited by William White (New York: New York University Press, 1978), 3:764-770.

2 Quotations from "The Sleepers" are from Walt Whitman, Leaves of Grass, Comprehensive Reader's Edition, edited by Sculley Bradley and Harold W. Blodgett (New York: New York University Press, 1965), pp. 424-433, with line numbers indicated parenthetically in the text. 
3 Daybooks and Notebooks, 3:764-765.

4 Daybooks and Notebooks, 3:764 and 765.

5 Daybooks and Notebooks, 3:770.

6 Daybooks and Notebooks, 3:765. 